\title{
THE CONCEPT OF IMAGO DEI IN THE THOUGHT OF GERRIT CORNELIS BERKOUWER
}

\author{
Farlen I. Tatukude ${ }^{1}$, Billy Kristanto ${ }^{2}$ \\ ${ }^{1}$ Gereja Reformed Injili Indonesia Ngagel \& Graha Family, Surabaya \\ ${ }^{2}$ Sekolah Tinggi Teologi Reformed Injili Internasional \\ Correspondence: farlen28@gmail.com, bkrstn@yahoo.com
}

\begin{abstract}
Gerrit Cornelis Berkouwer was a significant Dutch Reformed theologian. This article will observe Berkouwer's concept of imago Dei based on systematic-biblical method. In other words, biblical concept will only support the systematic-theological based discussion. It will be demonstrated through this article that, in comparison to previous approaches of explaining the concept of the image, Berkouwer had made a significant contribution. That contribution is found in his emphasis on the functional aspect of being the image. In doing this, on one hand, he followed the path of Reformatory tradition, but on the other hand, he also diverted from the Reformatory tradition on some issues about the concept of the image.
\end{abstract}

KEYWORDS: Berkouwer; imago Dei; human nature; human dignity; Postmodernism; analogia entis; analogia relationis; analogia amoris

ABSTRAK: Gerrit Cornelis Berkouwer adalah teolog Belanda yang penting dalam mewakili tradisi teologi Reformatoris. Artikel ini akan membahas konsep gambar Allah dari Berkouwer berdasarkan metode sistematika-biblika. Dengan kata lain, konsep biblika hanya sebagai pendukung bagi pembahasan yang berdasarkan teologi sistematika. Lewat artikel ini akan ditunjukkan bahwa Berkouwer memberikan sumbangsih bagi perkembangan konsep gambar dan rupa Allah dibandingkan dengan pendekatan-pendekatan yang dilakukan sebelumnya. Sumbangsih tersebut terletak pada penekanan aspek fungsional yang dia tunjukkan pada konsepnya. Dalam melakukan hal ini, di satu sisi Berkouwer mengikuti tradisi Reformatoris, tetapi di sisi lain, Berkouwer menunjukkan perbedaan dibanding dengan tradisi Reformatoris dalam menjelaskan gambar Allah. 
KATA KUNCI: Berkouwer; imago Dei; natur manusia; martabat manusia; Postmodernisme; analogia entis; analogia relationis; analogia amoris

\section{Introduction}

Throughout the history, theologians have been providing explanations about the meaning of the image of God. To begin with, it can be generally argued that the consensus of theologians until around the $16^{\text {th }}$ century was that the image of God was found in the mind or rational soul that God gave to Adam and that distinguished him from the animals. ${ }^{1}$ This kind of approach is called analogia entis (analogy of being) in explaining the image of God because those theologians attempted to seek the Godlike ontological characteristic found in human beings. However, there was a major turn in the $20^{\text {th }}$ century where a different approach was taken. This approach was based on the analogy of relation (analogia relationis), in which those theologians categorized under this approach was looking for God - human relationship and human - human relationship as where the image consists of. Therefore, the image of God is no longer based on human's ontological qualities as proposed by the proponents of analogia entis approach. ${ }^{2}$ By interacting with these two concepts, Berkouwer produced his own unique concept of imago Dei, which he named as the analogy of love (analogia amoris). It is the contention of this article to demonstrate that, in producing such concept, Berkouwer had made a significant contribution in explaining the image in comparison to those two concepts, as he emphasized on the functional aspect, in which being the image is no longer found in any substantial quality or relational capability, but rather on conformity to Christ in concrete and visible actions to others. ${ }^{3}$ Moreover, this article also aims to argue that, in establishing his concept, Berkouwer had preserved the Reformed tradition on some issues; but on some other issues, his position was not entirely Reformed.

\section{Method}

The method that will be used in this article is based on qualitative approach. This approach will be conducted through literary review on the concept of imago Dei. Berkouwer's book on the concept of man will be the primary sources to analyze his concept of imago Dei. In addition to that, some other

\footnotetext{
Gerald Bray, God is Love (Wheaton: Crossway, 2012), 382.

2 G. C. Berkouwer, Man in the Image of God, trans. Dirk W. Jellema (Grand Rapids: Eerdmans, 1962), 59.

3 For more explanation on the dynamic functionalism concept of the image, see Paul Wells, "In Search of the Image of God: Theology of a Lost Paradigm," Themelios, Autumn, 2004.
} 
writings of other theologians on imago Dei will also be considered to support the analysis of Berkouwer's concept. Hence, those theologians are considered only if they are related to the main topic of this article. That implies there will be no full outline of the historical development of the concept of imago Dei. Having compiled all those relevant sources, the analysis of this article will be based on systematic-biblical approach, in which the discussion is centered mainly on systematic theological issues. The biblical concept will act as a support to enhance the discussion on systematic ideas related to Berkouwer's concept of the image. That means, there is a limitation in this article that there will also be no full outline of the biblical concept of the imago Dei.

The analysis of this article will be presented in such a way: the first part of this article will discuss briefly about some approaches established by some theologians in explaining imago Dei, namely the approach of analogia entis and analogia relationis. Those approaches will present the theological context for Berkouwer to initiate his own distinctive concept. Secondly, Berkouwer's method will be explained thoroughly, whilst providing comparative analysis with those previous approaches. In doing this, this article hopes to demonstrate two things, namely some important contributions of Berkouwer's idea in explaining the image, and how Berkouwer preserved the Reformed tradition in composing his concept. The last part will discuss some objections to Berkouwer's concept of imago Dei, whilst also providing a constructive critic related with those objections. In this part, it will be outlined how Berkouwer diverted from the Reformed tradition. It will be argued that this, one hand, led to some weaknesses on his concept; but, on the other hand, provided a theological conception of imago dei which has potential to be useful in public arena.

\section{A Brief Overview of Some Approaches of Imago Dei}

\section{Irenaeus}

As mentioned above, two general approaches of explaining the image will be discussed in order to bring them into interaction with Berkouwer's concept. The first one is the concept of the image based on analogia entis, in which the image of God lies in the Godlike characteristic found in human beings. We can see this from Irenaeus who thought that the image primarily consists of rationality. ${ }^{4}$ That understanding was influenced by Greek philosophers such as Plato, Aristotle, Philo who taught that reason was the highest and

\footnotetext{
4 See Irenaeus, Against Heresies, IV.4.3, in Ante-Nicene Fathers, vol. 1, ed. Alexander Roberts and James Donaldson (Grand Rapids: Eerdmans, 1953).
} 
most distinctive characteristic of human beings. ${ }^{5}$ However, considering the effect of the Fall, there was a dilemma in understanding the image because, on one hand, the basic qualities of human nature must be defended through the Fall; but, on the other hand, humans have lost direction in following the Creator's will. ${ }^{6}$ To come up with a solution, based on Genesis 1:26, Irenaeus taught that the "image" - where human rationality lies - was retained after the Fall, whereas the "likeness" - which the Spirit-given knowledge of divine truth was placed in human beings - was lost after the Fall. ${ }^{7}$ The likeness of God will only be restored in the redemption stage, when believers come to faith in Christ. ${ }^{8}$ The strength of this approach is in defending the dignity of human beings, despite of the Fall event. However, focusing the 'image' on human rationality could potentially reduce human dignity merely on rationalistic conception. ${ }^{9}$

\section{Thomas Aquinas}

This understanding of the image of God was carried forward into the Middle Ages, as it can be seen from Thomas Aquinas, who retained the influence of Greek philosophy in explaining the image. However, in comparison to Irenaeus, Aquinas did not differentiate between the word: image and likeness. ${ }^{10}$ For Aquinas, through the image, God endows humans with the natural light of reason to understand and love Him even after the Fall. ${ }^{11}$ In this case, Aquinas followed Irenaeus in teaching that the image was not lost after the Fall. However, in contrast to Irenaeus, he maintained that the knowledge and love of God is possible to exist even without the help of grace from the redemption process. This is because through the natural light of reason humans can know God as the first and preeminent cause of all things. ${ }^{12}$ Nonetheless, this does not mean that Aquinas ignored the importance of supernatural grace from God that is achieved through redemption. He conceded that the help of supernatural grace is important to restore corrupted humans, in order that they achieve the meritorious good of supernatural virtue in order to merit eternal life. ${ }^{13}$ The advantage

\footnotetext{
Cf. Anthony A. Hoekema, Created in God's Image (Grand Rapids: Eerdmans, 1986), 34.

6 Bernd Oberdorfer, "The Dignity of the Personhood and the Concept of the "Image of God," in The Depth of Human Person, ed. Michael Welker (Grand Rapids: Eerdmans, 2014), 215.

Cf. Irenaeus, Against Heresies, V.6.1.

Bray, God is Love, 382. Cf. 2 Cor. 3:18.

9 Oberdorfer, "The Dignity," 210.

10 Cf. Thomas Aquinas, Summa Theologica, I.93.2.

Cf. Ibid., Ia.93.9.

Hoekema, Created in God's Image, 37.

13 Aquinas, Summa theol., I-II.109.5. For Aquinas, supernatural grace enables human's reason to submit to God, and consequently, human's lower powers (appetites/desires, emotions) can be controlled by reason.
} 
of this position is that it still defends the dignity of human beings even after the Fall, and in fact, this dignity is valued more highly in comparison to Irenaeus' concept. This is because not only that humans can still possess a Godlike characteristic, which is their rational capability through the Fall, but in fact, they remain almost as they were before the Fall, only that they lost the gift of supernatural grace. ${ }^{14}$ However, for the Reformation theology, this concept of the image does not sufficiently consider the depraved effect of the Fall on human beings. ${ }^{15}$ On the basis of this objection, we will see the development produced by the Reformed theology in terms of defining the concept of the image of God.

\section{John Calvin}

The Protestant Reformation, particularly from the theology of John Calvin, on one hand, continued the previous tradition in terms of locating the basic principle of Imago Dei in human's mind, although in some occasions he also mentioned that the image concerns the whole person. ${ }^{16}$ Moreover, Calvin followed Aquinas in not distinguishing between image and likeness. ${ }^{17}$ However, in contrast to Aquinas, Calvin established a distinctive concept on the image based on Colossians 3:10 and Ephesians 4:24, in which the image of God is defined in terms of conformity to God, as it includes true knowledge, righteousness and holiness. ${ }^{18}$ Moreover, Calvin continued that these things, called as "original righteousness," were lost through the Fall. However, Calvin also stated that despite of the image being corrupted as sin has made humans spiritually dead, it is not entirely annihilated, but whatever that remains was a horrible deformity,.${ }^{19}$ That implies that, on one hand, humans have been depraved and misdirected due to the Fall and thus leaves no part of human beings free from the infection of sin; but, on the other hand, some traces of the image still remain in them. ${ }^{20}$ By formulating such balanced understanding of the image, Calvin differentiated between, what

14 Ibid. Following Hoekema's statement in his Created in God's Image, Aquinas mentioned that fallen humans have natural knowledge and love of God. In fact, in some just people, Aquinas in his Summa Theologica suggested that the image shines bright and beautiful. This shows that there is a downplay on the catastrophic effect of the Fall on the image of God.

15 Cf. Hoekema, Created in God's Image, 48.

16 Ibid., 42. See also John Calvin, Institutes of the Christian Religion, ed. John T. McNeill, trans. Ford Lewis Battles (Philadelphia: Westminster, 1960), I.15.3.

17 Calvin in his Institutes, I.15.3 shows two reasons for his argument: 1) in Hebrew, two words are used for emphasizing one thing; and 2) human being is called the image of God because of his/her likeness to God. These show that there is no reason to differentiate the definition between these two words.

18 Paul Wells, "In Search of the Image of God: Theology of a Lost Paradigm," Themelios, Autumn, 2004, 27.

19 Ibid.

20 John Calvin, Commentary on Genesis 1:26 (King trans. [Grand Rapids: Eerdmans, 1948]). 
is usually named as the narrower and the broader sense of the image. The narrower which consists of the "original righteousness" was lost through the Fall, whereas the broader which consists of those remaining traces (reason and will), though have been partly weakened and corrupted by $\sin .{ }^{21}$

In this case, Calvin made an important contrast with Aquinas, because for Calvin fallen humans are in total depravity. On the contrary, Aquinas only emphasized on the loss of supernatural natural grace through the fall, leaving humans insignificantly affected through the Fall, because they are still capable naturally to know God. This shows that the effect of the Fall is not so catastrophic. The implication that is intended by Calvin is that because of our depraved nature, there is no possibility at all for human beings to know God without the supernatural work of the Spirit through the Word of God. ${ }^{22}$ As the Spirit illumines the human's heart, the process of the renewal of the image begins and one will be enabled to reflect the glory of God. This task is usually called as "mirroring" God's righteousness. ${ }^{23}$ The understanding of the purpose of redemption taught by Aquinas and Calvin seem to differ here. For the former, the emphasis is on meriting the eternal life, but for the latter, it is to reflect the glory of God.

\section{Karl Barth}

So far, we have seen that the image of God is defined primarily based on the approach of analogia entis. However, as explained before, there is a turn in the $20^{\text {th }}$ century where different approach to explain the image of God is found. Karl Barth, the main proponent of this concept, taught that the image of God is based on God-human relationship and human-human relationship. ${ }^{24}$ Hence, in this case, Barth had left the approach taken by Irenaeus, Aquinas and Calvin. For Barth, because there exists a confrontational relationship between an I and the Thou in the Triune God, He created humans with the same capacity of confrontational relationship with God and that relationship can also be applied in the relation with their fellow humans..$^{25}$ Therefore, based on the relationship in God Himself, there is an analogy of relation between God-human relationship and man-woman relationship. For Barth,

21 Hoekema, Created in God's Image, 44. See also Seung-Goo Lee, "Calvin and Reformed Theologians on the Image of God," Unio Cum Christo, vol. 2, no. 1 (April 2016): 145.

22 Cf. Calvin, Institutes, I.6.2.

23 Ibid., I.15.3.

24 Berkouwer, Man in the Image of God, 59.

25 Karl Barth, Church Dogmatics, III/2 (Edinburgh: T. \& T. Clark, 1960), 76-77. Barth mentioned in his Church Dogmatics that humans are created as Thou that can be addressed by God and an I responsible to God. That confrontational I-Thou relationship can be applied also between humans, where one can be a Thou to his fellow and therefore himself an I in responsibility to this claim. See also Hoekema, Created in God's Image, 49-50. 
to remove that analogy is "tantamount to removing the divine from God as well as the human from man." ${ }^{26}$ So if we ask the question where is the image to be found? Barth concluded that "[an] encounter between I and Thou, man and woman... in this humanity it is a likeness of the being of its Creator."27

Berkouwer's concept of the image came into the scene in the context of responding to the concept of analogia relationis. He states:

... one cannot, in my opinion, place an analogia relationis over against analogia entis, as Barth wishes to do. Even if one accepts the criticism given by Barth against the analogia entis, one is not thereby compelled to accept an analogia relationis. For Scripture does not deal with "relation," but with a relation as it becomes visible in and through the reality of salvation. ${ }^{28}$

This shows that although Berkouwer was appreciative towards Barth's concept of the image, since he had freed himself from the approach of analogia entis, yet he still saw Barth's concept lacks the dynamism and concreteness of actualizing the status of the image of God in the real life. The question raised by Berkouwer was in what context can the image become concrete and visible? In this case, Berkouwer seemed to elevate the concept of the image into a more functional approach. For him, whenever the Scripture discusses the image of God, it is always in terms of new creation, being conformed to Christ in the process of sanctification. ${ }^{29}$ This means that being the image of God is not about human quality, either rationalistic or relational nature, but rather by faith. ${ }^{30}$ By faith, Berkouwer does not mean to exclude all kinds of rational and relational aspect; rather, he wants to relate anthropology to soteriology. In other words, it shows that his concept of the image is dependent on the doctrine of regeneration. In this way, he avoided the concept of imago Dei to be defined in a static nature a la analogia entis or analogia relationis, but in a functional nature since to be the image is to imitate Christ in terms of responding and resonating the love and mercy of God to others. ${ }^{31}$ Therefore, this leads Berkouwer to provide an alternative method in defining the image of God using the approach he called as analogy of love (analogia amoris). The rest of this article will discuss about that concept, but before that we need to observe Berkouwer's point of departure in explaining his concept of imago Dei.

\footnotetext{
26 Ibid., III/1, 195.

Ibid., III/2, 203.

Berkouwer, Man in the Image of God, 101-2.

Cf. Berkouwer, Man in the Image of God, 112.

Oberdorfer, "The Dignity," 217.

Berkouwer, Man in the Image of God, 100.
} 


\section{Berkouwer' Concept of Imago Dei}

\section{Prolegomena to Berkouwer's Anthropology}

Having briefly stated in the previous part about Berkouwer's concept of imago Dei, the next step is to explain Berkouwer's compositions of ideas which then led him to conclude his concept of imago Dei. We will begin with his approach of understanding human beings. To achieve a true understanding of human beings that corresponds to the reality and can be accounted biblically, Berkouwer rejects what he called as a scientific approach in defining human beings (e.g. soul, body, spirit). He stated that any scientific definition does not guarantee that the true concept of human being can be obtained since all scientific methods are only based on some aspects of human being, not the whole person. Berkouwer argued this point based on his biblical exegesis works on the event of Creation, Fall/Redemption and Consummation.

For Berkouwer, in relation to the Creation, when the Bible says that man becomes a living soul through God's creative work, it does not say that man has a soul, as in the dichotomist concept (i.e. soul vs. body), but rather man is a living soul which reveals his complete createdness in his whole existence before God. ${ }^{32}$ In the case of Redemption, Berkouwer maintained that there is no ontological explanation in terms of the redemption since the whole person is restored and saved. Implied to that, the effect of the Fall also included the whole aspect of a person. Hence, for Berkouwer, Christ did not only die for the believers spiritually but also physically, which shows that the redemption includes the total existence of human being. Lastly, in relation to the eschatological period, according to Berkouwer, the believers will be resurrected with the newly resurrected body as a whole person of human being. ${ }^{33}$ Hence, for Berkouwer, throughout the Bible, human being is always witnessed in this religious relationship as a whole person, be it in his or her creatureliness, fall, vanity, mortality or superficiality. ${ }^{34} \mathrm{He}$ summed up his anthropological approach in this way:

the relation of man's nature to God is not something which is added...; it is essential and constitutive for man's nature, and man cannot be understood apart from this relation. An abstract view of man which ignores this relationship [will lead to] the unavoidable result that... no longer refers to actual man, real man, man as he really is... [and] Man without this relationship cannot exist, he is a phantom, a creation of abstracting thought. ${ }^{35}$

32 Ibid., 215.

33 Cf. 1 Cor. 15:35-58.

34 Berkouwer, Man in the Image of God, 34. Cf. Pro. 7:29, Gen. 12:27, Gen. 3, Rom. 5, Psa. 60:13, James 2:20, 1 Sam. 16:7, Job 33:12, Hos. 11:9, Psa. 39, 90.

35 Ibid., 23. 
By constructing such concept, on one hand, Berkouwer has followed the path set by other Reformed theologians who have been consistent in saying that the whole person is the imago Dei. ${ }^{36}$ On the other hand, Berkouwer has laid out a foundation for his concept of the image to be no longer based on any ontological qualities such as human mind/ratio as outlined above by Irenaeus and Aquinas, but instead on dynamic relation before God. Based on Berkouwer's view of humankind outlined above, now his theory of the image will be discussed.

\section{Becoming the Image}

Based on the concept of human beings stated above, we can now explain the construction of Berkouwer's concept of imago Dei. According to him, as human beings must be defined based on their religious relationship with God, hence the true essence of being the image of God is to admit one's misery and at the same time acknowledge God's grace for him or her. That means someone is not inherently an image of God, because to be classified as imago Dei includes a process of becoming. To be human is to be related to God in any natural conditions (creatureliness, fall, vanity, mortality, superficiality, etc.), but to become the image is to acknowledge one's sin and God's redemption. In other words, to be the image is to experience the process of regeneration. He states that the image "cannot be better known from anything than the reparation of human's corrupted nature." 37 This is because "the image of God stands before us in the contexts of guilt and restoration, of being lost and being found." ${ }^{38}$ Hence, to be the image includes, on one hand, a redemptive grace given by God independent of any human achievements, and on the other hand, human responsibility in which one is responsible to admit his sin and answer God's redemptive call by faithfully turning to Him. On this point, Berkouwer is in line with the Reformed teaching, as he owed his concept to Calvin. This is because as explained above, Calvin insisted that to be renewed as the imago Dei, human's heart must be illumined by the Spirit. This shows that it is not a form of human's achievement, but by grace because it is the work of the Holy Spirit through the Word to regenerate. ${ }^{39}$ Nevertheless, human's "special duty (is) to give

36 See Herman Bavinck, Reformed Dogmatics, vol. 2, God and Creation, trans. John Vriend, ed. John Bolt (Grand Rapids: Baker Academic, 2004), 559; John Murray, "Man in the Image of God," in Collected Writings of John Murray, vol. 2, Systematic Theology (Edinburgh: Banner of Truth, 1977), 39; Louis Berkhof, Systematic Theology, (Grand Rapids: Eerdmans, 1941), 207.

37 Berkouwer, Man in the Image of God, 88.

38 Ibid., 117.

39 T. F. Torrance, Calvin's Doctrine of Man (London: Lutterworth, 1949), 80. See also Hoekema, Created in God's Image, 46. 
ear to the Word of God" in order to faithfully turn to Christ. ${ }^{40}$

Berkouwer continued that the revelation of human sin and God's grace is found in the cross of Christ. He further maintained that "the cross is the revelation of God's love, but also at the same time, of his holiness and justice [toward human sin]"41 This follows that the cross discloses our misery and God's forgiveness. ${ }^{42}$ Thus, Berkouwer posits that there is only one possible source where we can become qualified as the image of God, and that is through faith in the cross of Christ. Without turning to faith in Christ, we are only nothing but an abstraction ${ }^{43}$ This means that for Berkouwer, to be the image is to acknowledge God as His Redeemer and consequently experiencing the process of new birth. Hence, it can be posited here that, according to Berkouwer, only the regenerated persons can become the image of God. Stated simply, anthropology is determined by soteriology. The next question that needs to be dealt with is why did Berkouwer come up with such concept? There are two reasons that will be discussed below, one is theological and the other is situational. The latter will be discussed first as it possibly affects the former.

Such theory of imago Dei proposed by Berkouwer was set situationally in opposition to the understanding of human's greatness proposed by the then-existing existentialism philosophy, particularly proposed by John Paul Sartre. ${ }^{44}$ In spite of the reality of human misery was discussed by both thinkers, Berkouwer argued that existentialism did not sufficiently encounter the reality of evil. For Berkouwer,

It [existentialism] is prepared to picture man in the unfathomable depths of hate and envy, in the abysses of egoism and angry menace, both in his conscious and unconscious aggressiveness towards his fellow man... It is prepared for a ripping off the masks, which will break through the illusions of bourgeois morality and show man for what he "actually" is. But this unmasking does not mean that humanism [existentialism] has accepted defeatism or hopelessness. For in and beyond this unmasking, a further goal is visible: ... the reaching towards... [the] basic aspect of human nature [that is] hidden behind the "actual" man. ${ }^{45}$

From the quote above, it was indicated by Berkouwer that existentialism still appealed to the greatness of human beings that can still be found within human life despite of its misery. This could threaten, argued by Berkouwer,

40 Calvin, Institutes, I.6.2.

41 G. C. Berkouwer, Sin, trans. Philip. C. Holtrop (Grand Rapids: Eerdmans, 1971), 199.

42 Ibid.

43 Berkouwer, Man in the Image of God, 93.

44 Cf. Bryan Magee, The Story of Philosophy (New York: DK Publishing Co., 2001), 216.

45 Berkouwer, Man in the Image of God, 25. 
the concept of salvation by God's grace alone as humans can still appeal to their own goodness to attain salvation. ${ }^{46}$ For him, following Reformed teaching, salvation does not come from within one's own goodness, but rather from the righteousness of God given by grace. To be able to internalize such reality of salvation, Berkouwer maintained that one must accept his or her total hopelessness due to the radical power of evil through the Fall, and consequently ask for God's mercy. This is in contrast with what is suggested by existentialism approach above. It can be concluded that Berkouwer wanted to exalt God's work in salvation and debase human greatness due to the Fall; whereas, Sartre opted for human exaltation by ignoring God. Such vision influenced Berkouwer's theory of the image, which then makes it to be heavily burdened with soteriological concern. In other words, soteriology is the motivating factor for Berkouwer's anthropology.

Based on the vision above, now we need to discuss about the theological concept of imago Dei which influenced Berkouwer's own version. It can be argued that Berkouwer could have been influenced by the theory of the image taught by Martin Luther. Luther equated the image of God with the original righteousness (justitia originalis), which is the right relationship with God before the Fall. ${ }^{47}$ Then, he concluded that when the state of righteousness turned into rebellion due to the Fall, the status of the image also disappeared. ${ }^{48}$ In other words, Luther intended to state that the actual image consists only (limited to) in original righteousness, which is capable of being lost and indeed was lost through the Fall. ${ }^{49}$ Stanley Grenz argued that, in response to the teaching of medieval theologians who maintained that the status of being the image still remains in sinful humans, Luther intended to avoid the conclusion that-based on the existence of the image-humans have the natural capacity to know and love God without the grace of the God in the work of the Spirit. ${ }^{50}$ It can be seen here that Luther's notion of the image is related primarily to his doctrine of salvation, as he was being cautious not to give any room in his concept of the image for anyone to falsely conclude that salvation can be achieved by works, but not by faith alone. Hence, Luther maintained that the loss of original righteousness equals

46 Ibid

47 Reformed theologians generally agree that justitia originalis is based on Colossians 3:10 and Ephesians 4:24, which includes true knowledge, true holiness and true righteousness. These things are lost through the Fall.

48 Bavinck, God and Creation, 553.

49 Ibid., 549.

50 Stanley Grenz, The Social God and The Relational Self (London: Westminster John Knox Press, 2001), 163-164. See also Jan Rohls, Reformed Confessions: Theology from Zurich to Barmen, trans. John Hoffmeyer (Kentucky: Westminster John Knox Press, 1998), 78. 
to the loss of the image of God as well.

Berkouwer, facing a similar situation like Luther, pursued the same route in explaining the theory of imago Dei as had been laid down by Luther. As it has been demonstrated above that existentialism still appealed on the greatness of humanity despite of its misery, Berkouwer fought to maintain the radical effect of the Fall which should direct humans to accept their misery and consequently appeal to God's grace. Based on this purpose, Berkouwer adopted Luther's theory of the image of God in order that salvation will not be based on human effort, but rather on God's grace. In doing this, Berkouwer-following Luther's path-placed soteriology as the basis for his theory of imago Dei. This led him to make a radical claim that the image is also lost through the Fall (image = original righteousness) and those who have not come to faith are just mere humans related to God, but no longer the image of God because they are not regenerated. ${ }^{51}$

In this case, Berkouwer had taken a non-Reformed position because, following the lead of Calvin, most later Reformed theologians consistently claim that non-believers still remain as the image of God. ${ }^{52}$ As it has been explained above Calvin differentiated between the narrower sense and the broader sense of the image, in order to maintain the status of the image on unregenerate people, whilst also emphasizing on the catastrophic effect of the Fall. Here we can see that by Luther's influence, Berkouwer's anthropological position is not an entirely Reformed position. Nevertheless, Berkouwer's intention to emphasize on the depravity effect of the Fall on humankind could be appreciated as it is closer to the Reformed teaching, particularly of Calvin, in comparison to Aquinas, for example. Although Calvin did not posit that the image is totally lost through the Fall like Berkouwer did, however Calvin's concept of the image emphasized on the depraved effect of the Fall on humankind as he mentioned that the image "was not totally annihilated and destroyed in him (man), yet... whatever remains is frightful deformity." 53 On this point, Berkouwer made an additional contribution on the concept of imago Dei in comparison to analogia relationis and analogia entis method. This will be explained below.

51 Berkouwer, Man in the Image of God, 59. Cf. Berkouwer, Sin, 273, 275.

52 Seung-Goo, “Calvin,” 145. See also Bavinck, God and Creation, 559; John Murray, “Man in the Image of God," in Collected Writings of John Murray, vol. 2, Systematic Theology (Edinburgh: Banner of Truth, 1977), 39; Louis Berkhof, Systematic Theology, (Grand Rapids: Eerdmans, 1941), 207.

53 Calvin, Institutes, I.15.4. 
Having laid out parts of Berkouwer's concept of the image, particularly on how one can become the image of God, we can now analyze that concept by comparing it with the approach of the analogy of being and the analogy of relation. In comparison to analogia relationis method, it can be indicated that Berkouwer's theory consists of relational aspect. Recalling what is explained above, for Berkouwer, to be the image is to faithfully return to God, having admitted one's sin and Christ's redemptive grace for him or her. Hence, this shows that to be the image is to be related to God by faith. Although this theory of the image consists of relation to God, it will be argued that such notion of relation is different to the concept of relation found in analogia relationis approach. This is because the idea of relation proposed by Barth is an abstract relation that is not laid out in the framework of the biblical-redemptive story, but rather only based on objective comparison between the Triune God and humankind. Hence, it is only, like what Berkouwer mentioned, an abstract relation which has no concrete and visible form. ${ }^{54}$ In contrast to that, Berkouwer's concept between God and His people is concrete because in his conception, he took into account the concrete reality of the Fall event, and thus the salvific work of Christ on the cross is included as well because to be the image one has to admit his or her own sin and God's restorative grace. And the result of it is that the experience of new birth, where one is now in union with Christ and undergoes the process of sanctification in order to be conformed to Christ continually. Consequently, this concept of the image is demonstrated visibly in the form of a new creation of His people. Hence, it can be concluded that Berkouwer's concept of the image is more biblical in comparison to analogia relationis version.

Having compared with analogia relationis method, now, we are going to compare with analogia entis approach. The strength of Berkouwer's concept of the image is that the focal point of being the image is not found in one's individual ontological quality (i.e. ratio), but rather it is a gift provided by God based on Christ's salvific work, which then calls for His people to accept that gift by faith. Two conclusions that can be drawn here: Firstly, Berkouwer had demonstrated a more biblical approach compared with the proponents of analogia entis method that relied on philosophical approach. Secondly, related to the salvific redemptive approach, Berkouwer has significantly considered the depraved effect of the Fall in composing his concept of the image. This is in contrast with Aquinas, who posited that humans have still 
inherited the aptitude for understanding and loving God through the Fall. ${ }^{55}$ In fact, according to him, some just people despite of being in fallen state, are habitually loving God, though still imperfectly. ${ }^{56}$ It can be indicated that the effect of the Fall, for Aquinas, has not totally depraved human status as the image, since humans were left almost in the same condition just like the original state. ${ }^{57}$ This is in opposition to what is witnessed in the Scripture regarding the devastating effect of the Fall on human beings. ${ }^{58}$

\section{The Function of Being the Image}

Having explained about the concept of the image, where one can be called the image as far as he or she has come through the process of regeneration, Berkouwer further states that everywhere when the Scripture discusses the new creation, it clearly directs our attention to our conformity with Christ. ${ }^{59}$ That means, for Berkouwer, the function of being the image is to essentially imitate Christ visibly in this world. According to Berkouwer, Christ is the focus because He is the model of being the image of God as He is the perfect image of God..$^{60}$ It can be stated that whilst the foundation of Berkouwer's version of imago Dei is soteriological, the pinnacle of it is Christological.

Berkouwer further suggested that those who are called to imitate Christ are those who are in union with Him. This is in accordance to what Paul taught in Corinth that anyone who is in Christ is a new creation (2 Corinthians 5:21). That means if to become the image, according to Berkouwer, one must be regenerated as a new creation, then it can be concluded that being an imago Dei is after all to be in union with Christ. Hence, we can only be the image if we are in the Image. ${ }^{61}$ Consequently, this union results to a dynamic progressive relationship between Christ and His people, as they are called to keep reforming their lives according to Himself. This means that to be the image of God does not only stop at the regeneration phase, which will then make the concept of imago Dei as fixed and static, but rather to be the image is a dynamic process as someone experiences the process of sanctification. In fact, Berkouwer posited that such process continues to the eschaton period, where the elects will attain

\footnotetext{
55 Aquinas, Summa, I.93.2.

56 Ibid.

57 Cf. Hoekema, Created in God's Image, 40.

58 Cf. Romans 3:23; Ephesians 2:1; Ezekiel 37:5,11,14, etc.

59 Berkouwer, Man, 100. Cf. Colossians 3:13, 16; 2:6; Ephesians 5:25; Philippians 2:5; 1 Corinthians

60 Cf. Colossians 1:15; Hebrews 1:3.

61 Wells, "In Search." 31.
} 11:1; Romans 8:29. 
full conformity with Christ. ${ }^{62}$ In this process, comes the work of the Holy Spirit who guides one's life in order to be able to imitate Christ dynamically up to the point of eschaton. It can be observed here that Berkouwer's concept contains not only Christocentric goal, but in order to support the elects accomplishing that goal up to the point of eschaton, a pneumatology aspect is also included in his theory.

The goal of imitating Christ, for Berkouwer, is concretely and visibly demonstrated by imaging Christ in His love and mercy toward others as the fruit of the new creation. ${ }^{63}$ That is demonstrated Christ's act of incarnation all the way to crucifixion with the mission to free others from the bondage of sin and to bring glory for God. ${ }^{64}$ Hence, the model of fulfilling the task of being the image of God is the kenosis of Jesus Christ. ${ }^{65}$ That implies that the essence of being the image is not only a static union in Christ, but a functional union in the form of imitating His work towards others. Just as witnessed by the Gospel of John that Christ's active union with the Father and the Spirit bore fruit in Christ's incarnation and ministry into this world, then the active union between Christ and His people too has to bear fruit in the ministry of the elects into the world ${ }^{66}$ In doing that, Christ witnessed His union with the Father through His work on earth (John 14:12), and in the same spirit, the images of God also witness their union in Christ through their merciful works toward others. Stated simply, to be an image is to be in communion with the Triune God and that communion will be extended to the communion with others as well. ${ }^{67}$ This is in accordance to Jesus' Final Prayer recorded in the Gospel of John, in which He said: "that all of them may be one, Father, just as you are in me and I am in you. May they be in us so that the world may believe that you have sent me" (John 17:21).

In executing that purpose above, Berkouwer states that being the image fulfills the Great Commandment, which is to "love the Lord your God with all your heart, soul, and mind; and to love your neighbor as yourself (Mat. 22:37-39). Based on this, for Berkouwer, to be the image includes a missional orientation in this world in the form of sacrificial life for the sake of others and God's glory.$^{68}$ In this case, Berkouwer's concept of the image shows that ethics and anthropology are inseparable. Stated

\footnotetext{
Berkouwer, Man in the Image of God, 106. Cf. 1 John 3:2.

Ibid., 97.

Cf. Philippians 2: 6-7.

Berkouwer, Man in the Image of God, 110.

Cf. John 1:1, 2, 9.

Cf. John 17:21.

8 Berkouwer, Man in the Image of God, 110.
} 
differently, Christian ethics can only be fulfilled through the right concept of anthropology. Consequently, it can be concluded that Berkouwer's concept has a dynamic-functional notion because to be the image is to fulfill a spiritual-ethical task. In other words, the spiritual union with Christ bears its fruit concretely in the ethical action of serving others. This means the fundamental motivation to love neighbor is produced by having a union with Christ. ${ }^{69}$ This is because love is from God and hence "if God so loved us, we also ought to love one another" (1 John. 4:7,11). This is the essence of Berkouwer's approach of analogia amoris (analogy of love).

The analogy lies in the fact that to be the image is to reflect God's love to others, as one has already received God's love. Therefore, according to Berkouwer, crucial in applying this analogy is "the link between forgiveness and readiness to forgive, between receiving mercy and being merciful." ${ }^{70}$ As one has received God's forgiveness and thus became regenerated, this leads him/her to reflect God's forgiveness to others. In doing this, one fulfills his/her calling to be the image of God. This is the heart of Berkouwer's concept of the analogy of love. The end purpose of practicing this analogy, for Berkouwer, is that the glory of God can be manifested through human beings living out their "imago Dei" status visibly and concretely in the reality of life. Berkouwer's point of being the image is best summarized by Gordon Spykman, who echoed Berkouwer's idea in his book Reformational Theology: "For man is not an ontic "copy" of God, nor a substantial "duplicate," but as the image of God we are called at a creaturely level to reflect, mirror, and echo the will of God in our life together in God's world." ${ }^{\prime 1}$

It can be demonstrated from the explanation above that Berkouwer's theory of the image incorporates a salvific-redemptive history as he included not only the aspect of regeneration, but also sanctification and even the eschatological aspect as well. He did not only consider the depravity of human beings in composing his version of imago Dei, but also the union with Christ in order to be able to conform with Him as the perfect Image of God and thus, reflect the glory of God. All these show that Berkouwer had made himself aligned with Calvin's teaching. Calvin, in his theory, as explained above taught that the image, that was greatly deformed due to

69 Ibid. Cf. Berkouwer, Faith and Sanctification, trans. John Vriend (Grand Rapids: Eerdmans, 1952), 106.

Berkouwer, Faith, 149

71 Gordon J. Spykman, Reformational Theology: A New Paradigm for Doing Dogmatics (Grand Rapids: Eerdmans, 1992), 205. Spykman agrees with Berkouwer as he cited Berkouwer's statement (Berkouwer, Man, 31) in regard to the concern of the Scripture about man: "it is clear enough from Scripture that its concern is with the whole man... as he stands in... the religious bond between the totality of his being and God." 
the Fall, can only be restored through the process of regeneration as the righteousness of God is given to His people by faith in Christ. Having been reborn in the Spirit, the elects are called to reflect or mirror Christ. ${ }^{72}$ That process of mirroring, according to Calvin, will only attain its full splendor in heaven. ${ }^{73}$ Hence, it is clear that Calvin's version of the image is a redemptive-historical one, and that model is preserved by Berkouwer.

In addition to that, Berkouwer also added his own distinctive ideasarguably influenced by the theology of the John's Gospel-into his concept of the image. He included the functional aspect of being the image in the form of ethical responsibility, which is to bring mercy and love towards others. This ethical task is a fruit of being in active union in Christ as the image of God. This shows that to be the image is not only connected to such an exclusive union with Christ, but that union must be extended inclusively towards others in the form of loving and merciful action. The extension towards others does not come by force but rather motivated by the love of God experienced by the union with Christ. In other words, the love of others comes from the love of God. This is the heart of Berkouwer's concept of analogia amoris.

In composing such concept, Berkouwer had provided some reasons on why he disagreed on Barth's concept of analogia relationis. For Berkouwer, Barth's theory lacks dynamism and visibility because, although it speaks about relation between God and humanity, it is only a fixed relation based on objective comparison between God and humans. ${ }^{74}$ In other words, following Anthony Hoekema's critique, Barth's view of the image is purely formal which only consists of the capacity for confrontation and encounter. ${ }^{75} \mathrm{He}$ did not demonstrate any concrete encounters in the relation between God-human relationship and human-human relationship. This is in contrast with Berkouwer, who showed that the relation between the image of God and God Himself is a dynamic-functional relationship as the image is called to imitate Christ visibly and concretely in His love and mercy towards others. Therefore, this union in Christ is not exclusive, but rather inclusive as it has been shown that such union is extended towards others as the image of God minister their love and mercy for others. The reason is because the union with Christ is a union in His works towards others in this world.$^{76}$ The source of that external works towards others comes from

\footnotetext{
72 Hoekema, Created in God's Image, 47.

Calvin, Institutes 1.15.4.

See the Introduction section that explains about Barth's theory of the image.

Hoekema, Created in God's Image, 52.

Cf. John 14:12.
} 
the love from God experienced in the union with Christ. That is the heart of the analogy of love proposed by Berkouwer.

Barth, with his analogia relationis view of the image, had only shown that to be the image is to possess a capacity in having a confrontational I-Thou relationship between fellow humans; however, Berkouwer had gone further than Barth by giving content to that formal relationship, and that is found in the action of dispensing Christ's love and mercy to others. For Berkouwer, that is the product of being the image of God. This again confirms that Berkouwer's concept contains a dynamic-functional notion of being the image in comparison to analogia relationis approach.

\section{Objections to Berkouwer's Concept of Imago Dei}

Having discussed Berkouwer's concept above, particularly its significant contributions in comparison to previous approaches in understanding the image, in this section there will be a discussion on the weaknesses of Berkouwer's concept of the image. The main objection that will be discussed in on the issue of human dignity, particularly on non-believers.

From Berkouwer's concept of the image above, one problem that can be observed is about unregenerate people whose dignity of being human comes into question. It has been clearly outlined above that only those who have experienced the new birth can be called as the image of God. Based on that, if the unregenerate cannot be defined as the image of God, then what is their dignity as humans? It can be implied that Berkouwer understood that the image of God seems to be nonessential to those unregenerate as they can still exist without it. ${ }^{77}$ How did Berkouwer deal with it?

To begin with, Berkouwer was aware with some parts of the Scripture that indicate the image of God is retained through the Fall. ${ }^{78}$ However, following the argument of a Dutch theologian named Klaas Schilder, Berkouwer then maintained that those verses do not refer to the status of the image through the Fall, but they refer to human's original status whose function is to remind that human being is the divine act of creation. ${ }^{79}$ Based on this, humans must be protected as they have what he called as "human's inviolable humanity." Berkouwer sums that up in this statement:

Thus, anyone who attacks his fellow man, or curses him, violates the mysterious essence of man, not because man is mikrotheos, or demi-god, but because he is man. In all his relations and acts, he is never man-in-himself, but always man-in-relation, in relation to this history of God's deeds in creation, to this

77 Berkouwer, Man in the Image of God, 64.

78 Cf. Genesis 9:6, James 3:9, and 1 Corinthians 11:7.

79 Berkouwer, Man in the Image of God, 54. See also the section on Prolegomena to Berkouwer's Anthropology. 
origin of an inalienable relation to his Creator. And this man is protected and maintained in his relation to God by Him. ${ }^{80}$

From the quote above, it can be seen that Berkouwer maintained the dignity of the unregenerate as merely human, whose self-worth is found in his or her relation to God. In this case, it can be argued that, following the lead of Luther, Berkouwer understood that humans have lost their status as the image through the Fall and what is left only their inviolable humanity. ${ }^{81}$ As it has been outline above, on this case, Berkouwer had taken a non-Reformed position because, following the lead of Calvin, most later Reformed theologians consistently propose the double aspect of the image (broader sense and narrower sense).$^{82}$ Berkouwer's tendency to emphasize on soteriological concern and Christocentric focus has caused him to overlook the creational aspect of being the image which should not have been lost through the Fall. Though we can understand Berkouwer's concern, yet as has been pointed out by Hoekema, Berkouwer fails to show that the image of God is essential to human existence. ${ }^{83}$ This creates some negative impacts which will be outlined below.

If human dignity is only based on the fact they are created by God, then it indeed denigrates, rather than, elevates their dignity in comparison to other lower creatures. For example in Genesis 6:9, according to Hoekema, the Scripture has clearly conveyed the implication of those verses that "to touch the image of God is to touch God Himself; to kill the image of God is to do violence to God Himself." ${ }^{44}$ This means that, not only that humans are related to God because He was their Creator, but there is a real presence of God attached to human beings and that makes them undeprivably and inescapably God's image. ${ }^{85}$ This shows that humankind must be considered as the image of God since the creation because that status is inherent in human life. Hence, to be the image is to possess a special quality, where God has elected and destined this species in whom His name is attached. ${ }^{86}$ If we do not preserve that inalienable dignity of human beings, then we risk being unbiblical and that obviously leads to some other socio-ethical problems. Those problems are important to be outlined because Berkouwer's theory of the image includes ethical aspect as well.

80 Ibid., 59.

81 For more explanation on Luther's influence on Berkouwer, see the section on Becoming the Image.

82 Seung-Goo, "Calvin," 145.

83 Hoekema, Created in God's Image, 64-65.

84 Ibid., 16.

85 Jurgen Moltmann, God in Creation: A New Theology of Creation and the Spirit of God (The Gifford Lectures) (Minneapolis: Fortress Press, 1993), 233.

86 Cf. Oberdorfer, “The Dignity," 217. 
According to Calvin, the fact that the remnants of the image of God still remain in all humans despite of sin, that becomes the undergirding principle to love one another, including our enemies. ${ }^{87}$ For Calvin, "if we rightly direct our love, we must first turn our eyes not to man, the sight of whom would often engender hate than love, but to God. ${ }^{88}$ That implies, the ethical function of being the image considered by Berkouwer which is to love God and others, can only be well-executed if we see others as the image of God. Therefore, by acknowledging the dignity of unregenerate persons as the image of God - not only as mere humans related to God-will precisely strengthen, as opposed to weaken, the function of being the image of God proposed by Berkouwer, which is to imitate Christ's love toward others. Stated simply, the theory of analogia amoris cannot be effectively applied if non-believers are not considered as the image of God. Consequently, Berkouwer, albeit unintentionally, weakened his own concept of the image by not giving the non-believers the dignity conferred by God since the creation. Therefore, his theory tends to be intolerant towards those who have not been regenerated by the grace of God.

This further shows, on the issue of human dignity, Berkouwer fell into the same trap as analogia entis method did, since both methods created a discriminative view on humankind. The latter approach could potentially create a discriminative view because the status of imago Dei is based on human rational capability ${ }^{89}$; whereas, the former discriminatively view humankind on whether one is being regenerated. Therefore, based on Berkouwer's concept, it becomes difficult for the church to present this anthropological conception in public life, such as in the issue of human rights or religious tolerance. This is because such concept is not inclusive enough to provide dignity for other religions and even non-religious people.

Hence, the last question that needs to be dealt is that how do we defend Berkouwer's concept of the image in public arena whilst providing theological argument that every human being is the image of God? Stated

87 Randall Zachmann, Reconsidering John Calvin (Cambridge: Cambridge Univ. Press, 2012), 38.

88 Calvin, Institutes, II.8.55. See also Zachmann, Reconsidering, 38. However, this statement by Calvin does not go without any limit, for him the limit is based on reason (influenced by the analogia entis approach). What Calvin meant by reason is the ability to do or judge what is good and evil. This capability is the practical aspect that remains in the image of God, albeit some are clearer compared to others. Therefore, according to Calvin, a drunk man denigrates himself into a beast because he can no longer clearly differentiates what is right and wrong. In this case, the reason to love him becomes less and in danger of becoming non-existent.

89 Regarding this point, Peter Singer, a leading ethicist, once mentioned that human individuals who permanently lack those abilities which are considered as normal in human beings (e.g. ratio, motoric movement, etc.) need not be addressed and treated as persons, whereas non-human individuals who possess those abilities have to be considered as persons and should enjoy same rights and protection as humans. Cf. Peter Singer, Practical Ethics (Cambridge: Cambridge University Press, 1979); See also Oberdorfer, "The Dignity," 212. 
differently, how do we establish Berkouwer's concept of the image that keeps the common unalienable human dignity based on the status of imago Dei, but at the same time, that modified concept is still centered around some important elements of Berkouwer's theory, such as its Christocentric focus, soteriological concern and ethical aspect as well?

To begin with, for Berkouwer, the central concept of being the image is that one must participate in Christ through the process of new birth. This follows that the new creation is only possible because of Christ's salvific work. Based on this Christological ground, we can construct a universal concept of anthropology. According to a theologian named Bernd Oberdorfer, the universality of Christ's work of salvation does not allow the exclusion of any individual a priori. ${ }^{90}$ What that means is that although based on Reformed doctrine of election, the concept of universalism in salvation is not accepted, it does not mean that we can limit Christ's work only to a limited group, but instead we have to see that it targets all people. In other words, of no one can it be claimed that he or she will not take part in the union with Christ. This principle becomes the foundation for us to preserve Berkouwer's concept of the image, on one hand, and on the other hand, defend the status of the image for unbelievers.

Based on that universal notion, consequently the unknown elects (i.e. unbelievers) are unknown de facto and consequently, considering Berkouwer's concept of the image, there should be no exclusion in classifying any person as non-image a priori (because for Berkouwer, the elects, those who are in Christ, are the image of God). Hence, Oberdorfer posits that "the universality of Christ's work of salvation commits Christians to treating non-Christians as people to which Christ's work is valid as well, although such persons do not (yet) know or ... acknowledge it." "91 Consequently, we cannot categorize unbelievers' status as non-image because there is a possibility, through the free work of the Spirit, that Christ's salvific work may be applied to them as well. The ethical task of the believers is to help them attain that conformity with Christ by, according to Berkouwer's concept, imitating Christ's mercy and love towards them.

The strength of this argument is that all persons can now be acknowledged as potentially holding the status of the image and that makes everyone, conceptually, able to possess the inviolable human dignity. In doing that, the universal anthropology is attained. Moreover, in the concept above, the Christocentric focus combined with soteriological concern can still be

90 Oberdorfer, “The Dignity," 218.

91 Ibid. 
preserved. In fact, the ethical aspect of Berkouwer's concept of the image can be considered as well. To sum up, by incorporating some ideas from Oberdorfer, we have demonstrated that Berkouwer's concept of the image could be useful in public life, because it can include a common unalienable human dignity, namely, the imago Dei for all people. And, at the same time, it does not lose those important elements of Berkouwer's theory, which was typically Reformed.

\section{Conclusion}

To conclude this article has demonstrated how Berkouwer's concept of imago Dei produced some significant contributions in comparison to analogia entis and analogia relationis approach that preceded Berkouwer's time. Some points that can be summarized are: Firstly, Berkouwer took a more biblical approach as he laid out his theory of imago Dei in the form of redemptive-biblical story, as opposed to a more philosophical and abstract approach taken by other approaches. That means, in his conception, he emphasized on the depraved effect of the Fall on humankind, then Christ's salvific work is considered, and the union with Christ experienced in the creation is also examined. Hence, Berkouwer's version of the image consists of dynamic-functional element as the image, who is in union with Christ, is called to be continually conformed to Christ. Furthermore, that union is not exclusive but rather inclusive, as the function of being the image is to resonate Christ's love and mercy towards others. Therefore, in contrast to analogia relationis approach which only emphasized on the formal relationship: the capacity for encounter, Berkouwer's concept proposed a rather more visible and concrete relation to God and others.

In presenting such concept, Berkouwer preserved the Reformed tradition on understanding the image of God on some points. Some notable points are his concept of imago Dei as a whole person, his emphasis on the process of regeneration to become the image of God and the significance of imitating or mirroring Christ's love and mercy towards others in order to reflect the glory of God. That last point is the crux of his analogia amoris concept. However, on some other points, Berkouwer's position is not entirely Reformed as it can be seen in his insistence to consider the image as non-existent in non-believers, which then led to a low view on human dignity. Consequently, this created some difficulties in presenting Berkouwer's concept in public life. However, a constructive critic has been provided which makes Berkouwer's concept to be potentially useful in public arena. 